\title{
PERLINDUNGAN HUKUM SAKSI DAN KORBAN SEBAGAI WHISTLEBLOWER DAN JUSTICE COLLABORATORS PADA PENGUNGKAPAN KASUS KORUPSI BERBASIS NILAI KEADILAN
}

\author{
Suratno \\ Kejaksaan Tinggi Jawa Tengah \\ suratno9999@gmail.com
}

\begin{abstract}
The question of Whistle blower or Justice Collaborator is a complex and interesting issue to be discussed in a conception or legislation. The role of Whistle Blower and Justice Collaborator in exposing such extraordinary crimes as corruption is a dilemma, because there is no adequate legal tool to facilitate the legal guarantee to be obtained. The research approach used in this research is sociological or socio-jurisdiction approach method-legal research. The results of the research indicate that: 1 . The protection of the witness and victim's witness law as Whistleblower and Justice Collaborators on the disclosure of corruption has not been based on the value of justice, it can be seen that the legal status of a whistle blower does not stop only whistle blowers, Be someone to be held accountable. 2. Legal protection barriers to the existence of Whistleblower and Justice Collaborators on the disclosure of corruption based on the value of justice, known from the side of the substance of the law is the weakness of the arrangement of Justice collaborator explicitly regulated only in Supreme Court Circular Number 4 of 2011 on the treatment of rapporteur of acts $A$ Whistleblower and a Justice Collaborator in a particular criminal case, so that the SEMA does not have a binding legal force as does the Law.
\end{abstract}

Keywords : Legal Protection, Whistleblower \& Justice Collaborator, Criminal act of corruption

\begin{abstract}
Abstrak
Persoalan mengenai Whistle blower ataupun Justice Collaborator merupakan persoalan yang rumit sekaligus menarik untuk dibahas dalam suatu konsepsi ataupun legilasinya. peran Whistle blower maupun Justice Collaborator dalam mengungkap suatu kejahatan-kejahatan luarbiasa seperti tindak pidana korupsi merupakan suatu dilemma, karena belum adanya perangkat hukum yang memadai untuk memfasilitasi jaminan hukum yang akan didapat, Pendekatan penelitian yang digunakan dalam penelitian ini adalah metode pendekatan yurisdissosiologis atau sociolegal research. Hasil dari penelitian menyebutkan bahwa: 1.Perlindungan hukum keberadaan saksi dan korban sebagai Whistleblower dan Justice Collaboratos pada pengungkapan korupsi belum berbasis nilai keadilan, dapat diketahui bahwa status hukum dari seorang whistle blower tidak berhenti hanya sebatas whistle blower saja, suatu saat kedudukan tersebut dapat berubah menjadi seseorang harus dimintai pertanggung jawaban. 2. Hambatan-hambatan perlindungan hukum bagi keberadaan Whistleblower dan Justice Collaboratos pada pengungkapan korupsi yang berbasis nilai keadilan, diketahui dari sisi substansi hukum adalah kelemahan pengaturan tentang Justice collaborator secara eksplisit hanya diatur dalam Surat Edaran Mahkamah Agung Nomor 4 Tahun 2011 tentang perlakuan bagi pelapor tindak pidana (Whistleblower) dan saksi pelaku yang bekerjasama (Justice Collaborator) di dalam perkara pidana tertentu, sehingga SEMA tersebut tidak mempunyai kekuatan hukum yang mengikat seperti halnya Undang-Undang.
\end{abstract}

Kata kunci : Perlindungan Hukum, Whistleblower \& Justice Collaborator, Tindak Pidana Korupsi 


\section{A. PENDAHULUAN}

Reformasi tahun 1998 telah membawa dampak yang sangat berarti bagi bangsa Indonesia, salah satunya adalah perubahan Undang-Undang Dasar Negara Republik Indonesia Tahun 1945 (UUD NRI 1945). Perubahan tersebut tentunya akan membawa dampak yang penting dalam ketatanegaraan Indonesia. Ir. Soekarno menyatakan bahwa UUD 1945 merupakan "Revolutie-Grondwet" atau "UUD Kilat" yang disusun sekedar untuk memenuhi kebutuhan dalam rangka sesegera mungkin memproklamasikan Indonesia sebagai negara merdeka. ${ }^{1}$ Namun demikian, dalam pemberlakuannya terus-menerus dipertahankan oleh para penguasa baik penguasa Orde Lama maupun saat pemerintahan Orde Baru sebagai dokumen hukum dasar yang bersifat sakral dan tak tersentuh oleh ide perubahan. Salah satu sebabnya ialah karena pokok ketentuan yang diatur dalam UUD 1945 itu memang sangat menguntungkan pihak yang berkuasa, karena sifatnya yang sangat executive heavy. ${ }^{2}$

Pada tahun 2012, Indonesia menduduki peringkat ke-118 sebagai negara paling korup dari 182 negara. ${ }^{3}$ Dan Peringkat Indonesia di indeks korupsi pada tahun 2015 yang dikeluarkan Transparency International naik dari 114 ke 107. Tapi masih jauh di bawah negara-negara tetangga seperti Filipina, Thailand, Malaysia dan Singapura. ${ }^{4} \mathrm{Hal}$ ini berarti, kondisi buruk korupsi di Indonesia masih belum banyak berubah dari tahun ke tahun. Peningkatan korupsi di Indonesia kini tidak hanya terjadi dari segi kuantitas, namun kualitas korupsi di Indonesia juga semakin meningkat. Maraknya pemberitaan mengenai jual-beli perkara, mafia hukum, mafia peradilan, mafia pajak, dan makelar kasus, mengindikasikan bahwa korupsi telah menjangkiti hukum itu sendiri.

1 Jimly Assiddiqie, 2007, Pokok-Pokok Hukum Tata Negara Indonesia Pasca Reformasi, PT. Bhuana IImu Populer,Jakarta, hlm. 230

2 Jimly Assiddiqie, 2001, Telaah Kritis Mengenai Perubahan Undang-Undang Dasar 1945, Jurnal Forum Indonesia Satu "Civility", Vol. 1, No. 2, November 2001-Januari 2002, Jakarta, hlm. 28-29

3 Transparency International, diakses dari http://cpi. transparency.org/cpi2012/results/

4 http://www.dw.com/id/indeks-korupsi-peringkatindonesia-membaik-tapi-masih-buruk /a-18107694, yang diakses pada tanggal 17 September 2016
Korupsi di Indonesia saat ini menjadi semakin sistematis dan terorganisir karena melibatkan para aparat penegak hukum. ${ }^{5} \mathrm{Hal}$ ini menjadi sangat ironis, sebab aparat penegak hukum yang seharusnya berfungsi menegakkan hukum justru mempermainkan hukum demi keuntungan pribadi dan golongan.

Berbicara tentang korupsi sebenarnya bukanlah masalah baru di Indonesia. Bahkan berbagai kalangan menilai bahwa korupsi telah menjadi bagian dari kehidupan, menjadi suatu sistem dan menyatu dengan penyelenggaraan pemerintahan negara. Penanggulangan korupsi dengan menggunakan perangkat perundang-undangan yang ada masih banyak menemui kegagalan. Keadaan demikian akan menggoyahkan demokrasi sebagai sendi utama dalam kehidupan berbangsa dan bernegara, melumpuhkan nilai-nilai keadilan dan kepastian hukum serta semakin jauh dari tujuan tercapainya masyarakat sejahtera. Dengan melihat latar belakang timbulnya korupsi, salah satu faktor yang menyebabkan meningkatnya aktivitas korupsi di beberapa negara disebabkan terjadinya perubahan politik yang sistemik, sehingga tidak saja memperlemah atau menghancurkan lembaga sosial politik, tetapi juga lembaga hukum. Penegakkan hukum terhadap tindak pidana korupsi, kehadiran saksi (termasuk pelapor) sangat diperlukan mengingat sulitnya bagi aparat penegak hukum dalam menyelesaikan suatu tindak pidana yang ditangani apabila tidak adanya kehadiran saksi (termasuk pelapor). Tidak banyak orang yang bersedia mengambil resiko untuk menjadi whistleblower dan mengungkapkan fakta suatu tindak pidana korupsi jika dirinya, keluarganya dan harta bendanya tidak mendapat perlindungan dari ancaman yang mungkin timbul karena pengungkapan kasus tersebut. Begitu pula dengan saksi Pelaku yang Bekerja Sama (justice collaborator), jika tidak mendapat perlindungan yang memadai, akan enggan memberikan keterangan sesuai dengan fakta yang dialami, dilihat, dan dirasakannya sendiri.

Sampai sekarang belum ada peraturan perundang-undangan yang secara khusus

5 Mahfud Md., Pemberantasan Mafia Peradilan, diakses dari http://www.mahfud md.com/index. php?page=web. MakalahVisit\&id=25 [27 September 2013]. 
mengatur mengenai whistleblower di Indonesia. Pengaturannya secara implisit termaktub dalam Undang-Undang No. 13 Tahun 2006 tentang Perlindungan Saksi dan Korban serta kemudian diikuti dengan Surat Edaran Mahkamah Agung Nomor 4 Tahun 2011 tentang Perlakuan terhadap Pelapor Tindak Pidana (whistleblower) dan Saksi Pelaku yang Bekerja Sama (justice collaborator).

Surat Edaran Mahkamah Agung RI tersebut diterbitkan dengan mendasarkan pengaturan Pasal 10 Undang-Undang No. 13 Tahun 2006 tentang Perlindungan Saksi dan Korban. Hal lainnya yang penting dari surat edaran tersebut bahwa perlakuan khusus untuk whistleblower dan justice collaborator tersebut hanya untuk kasus-kasus tindak pidana tertentu yang bersifat serius seperti tindak pidana korupsi, tindak pidana terorisme, narkotika, pencucian uang, perdagangan orang, serta tindak pidana lainnya yang menimbulkan masalah dan ancaman yang luas. Sementara dalam SEMA Nomor 4 Tahun 2011, whistleblower diartikan sebagai pihak yang mengetahui dan melaporkan tindak pidana tertentu dan bukan merupakan bagian dari pelaku kejahatan yang dilaporkannya. Namun demikian dalam praktiknya kadang whistleblower juga terlibat dan memiliki peran yang kecil dalam kejahatan tersebut.

Saat ini praktik-praktik sistem pelaporan dan perlindungan whistleblower di Indonesia belum sepenuhnya dilaksanakan secara luas di lembaga-lembaga pemerintahan atau lembaga negara, institusi-institusi publik atau sektor swasta. Negara ini sangat jauh tertinggal dari negara-negara lain, seperti Amerika Serikat (AS), Australia, dan beberapa negara di Eropa yang sudah lama menerapkan sistem pelaporan dan perlindungan whistleblower. Dalam ketentuan hukum positif Indonesia, Kitab Undang-Undang Hukum Acara Pidana (Selanjutnya disebut KUHAP) yang disebut-sebut sebagai karya agung dan merupakan salah satu pencapaian tertinggi bangsa Indonesia dibidang hukum, ${ }^{6}$ telah mencantumkan sedikit ketentuan yang sudah memperhatikan hak asasi tersangka/ terdakwa. Hal ini tercantum dalam ketentuan

6 Teguh Sulistia dan Aria Zurnetti, 2011, Hukum Pidana Horizon Pasca Reformasi, PT. Raja Grafindo Persada, Jakarta,hlm.9
Pasal 108 Ayat (1) KUHAP yang menentukan bahwa setiap orang yang mengalami, melihat, menyaksikan dan atau menjadi korban peristiwa yang merupakan tindakpidana berhak untuk mengajukan laporan atau pengaduan kepada penyelidik dan atau penyidik baik lisan maupun tertulis. Selain itu pada Pasal 117 Ayat (1) ditentukan bahwa dalam proses peradilan seorang saksi memiliki hak untuk memberikan keterangan kepada penyidik tanpa tekanan dari siapapun dan dalam bentuk apapun. ${ }^{7}$

Ketentuan dalam KUHAP tidak memberikan garis koordinasi yang kolaboratif mengenai perlindungan hukum hak pelapor maupun kepada saksi yang bekerja sama untuk mengungkap perkara pidana. Penempatan sebagai pelapor tindak pidana (Whistleblower) dan saksi pelaku yang bekerjasama (Justice Collaborator) dalam system peradilan yang menjadi masalah adalah dasar hukum untuk memberikan perlindungan hak asasi manusia. Ketentuannya belum terintegrasi dalam satu sistem sehingga belum dapat diterapkan sepenuhnya, oleh karena itu masih menimbulkan polemik di antara penegak hukum.

Whistleblower maupun Justice Collaborator dapat berperan besar untuk mengungkapkan praktik-praktik koruptif lembaga publik, pemerintahan maupun perusahaan swasta. Oleh karena itu, implikasinya tanpa adanya system pelaporan dan perlindungan Whistleblowerdan Justice Collaborator maka partisipasi public untuk membongkar dugaan tindak pidana menjadi rendah sehingga praktik penyimpangan, pelanggaran, atau kejahatan pun semakin meningkat. Akan tetapi, sebenarnya dimensi Whistleblower dan Justice Collaborator tidak hanya berorientasi sesuai konteks. Aspek ini lebih luas dapat dikatakan Whistleblower maupun Justice Collaborator dari perspektif formulasi serta praktiknya menimbulkan dilemaya itu dalam posisi bagaimana seseorang ditempatkan sebagai Whistleblower dan Justice Collaborator. Hal ini berarti, dari perspektif system peradilan pidana Indonesia pada posisi dimanakah eksistensi seseorang dapat disebut sebagai Whistleblower dan Justice Collaborator apakah

Friedrich, CJ, 2010, Filsafat Hukum Perspektif Historis, Nuansa dan Nusamedia, Bandung,hlm.45. 
parsial ditingkat penyidikan, penuntutan, peradilan, ataukah kolaboratif pada semua tingkat tersebut dimungkinkan. Selain itu, dalam tataran kebijakan formulatif dan aplikatif pada masa kini (Ius Constitutum) terdapat adanya kekurang jelasan, kekurang tegasan dan kekurang sempurnaan perlindungan hukum terhadap Whistleblower dan Justice Collaborator dibandingkan dengan pengaturan dibeberapa negara baik mengenai lembaga yang mengatur Whistleblower dan Justice Collaborator, pengaturan legislasi, mekanisme, dan lain sebagainya. Sehingga, konsekuensi logis dimensi demikian diperlukan untuk masa mendatang (lus Constituendum) adanya sebuah konsep ideal perlindungan hukum terhadap Whistleblower dan Justice Collaborator dalam rangka menanggulangi tindak pidana korupsi di Indonesia. Dari fakta yang ada penulis menentukan perumusan masalah yang akan di bahas dalam jurnal ini yaitu

1. Bagaimanakah perlindungan hukum terhadap keberadaan saksi dan korban sebagai Whistleblower dan Justice Collaboratos pada pengungkapan korupsi berbasis nilai keadilan?

2. Bagaimanakah Hambatan-hambatan perlindungan hukum bagi keberadaan Whistleblower dan Justice Collaborators pada pengungkapan korupsi yang berbasis nilai keadilan?

\section{B. Metode Penelitian}

Pendekatan penelitian yang digunakan dalam penelitian ini adalah metode pendekatan yuridis sosiologis atau socio-legal research. ${ }^{8}$ Metode pendekatan yuridis sosiologis dikarenakan permasalahan yang diteliti menyangkut hubungan antara faktor yuridis dan faktor sosiologis. Yuridis artinya penelitian yang didasarkan pada teori-teori hukum, khususnya yang berkaitan dengan model perlindungan hukum keberadaan whistle blower terhadap penegakan hukum di Indonesia. Dasardasar yang terdapat dalam perundang-undangan tersebut yang digunakan untuk menganalisis masalah. Sosiologis artinya penelitian yang berhubungan langsung dengan masyarakat,

\footnotetext{
8 Ronny Hannitijo Soemitro, 1990, Metodologi Penelitian Hukum dan Jurumetri, Ghalia Indonesia, Jakarta, hlm 14.
}

dapat dilakukan melalui pengamatan (observasi), wawancara ataupun penyebaran angket. Jadi, dapat disimpulkan bahwa pendekatan secara yuridis sosiologis adalah pendekatan penelitian hukum yang didasarkan pada aturan-aturan hukum yang berlaku dan dilakukan dengan pengamatan (observasi), wawancara ataupun penyebaran angket. Dalam penelitian ini, objeknya adalah keberadaan whistle blower pelaku-pelaku korupsi terhadap penegakan hukum di Indonesia.

\section{Pembahasan}

1. Perlindungan Hukum Terhadap Keberadaan Saksi Dan Korban Sebagai Whistleblower Dan Justice Collaborators Pada Pengungkapan Korupsi Berbasis Nilai Keadilan

Perlindungan hukum keberadaan saksi dan korban sebagai Whistleblower dan Justice Collaborator pada pengungkapan korupsi belum berbasis nilai keadilan, dapat diketahui bahwa status hukum dari seorang whistle blower tidak berhenti hanya sebatas whistle blower saja, suatu saat kedudukan tersebut dapat berubah menjadi seseorang harus dimintai pertanggungjawaban. Sesuai teori kepentingan negara melawan kepentingan individu, bahwa demi menunjang kepentingan negara dalam mengungkapkan suatu kejahatan whistle blower sebagai individu dapat dilepaskan dari bentuk pertanggungjawaban. Dengan demikian atas kepentingan negara, tujuan hukum berupa kemanfaatan maka perlu dibuat perlindungan hukum bagi whistle blower. Walaupun dari segi tujuan hukum kepastian hukum, apaapa yang telah dilakukan whistle blower dan perlu dimintai pertanggungjawaban maka haruslah ditindak secara tegas pertanggungjawaban.

Perlindungan hukum justice collaborator di Indonesia masih sangat lemah. Hal ini dapat dilihat dari segi: pertama, permasalahan riil yang menunjukkan kenyataanbahwa justice collaborator tidak mendapatkan penghargaan dan perlindungan, bahkan turut dijadikan tersangka atas kasus korupsi yang dilaporkannya; dan kedua, permasalahan materil dan formil dalam berbagai peraturan. 
Para justice collaborator di Indonesia turut dijadikan tersangka atas kasus korupsi yang dilaporkannya serta dikriminalisasi atas kasus lain. Contoh faktual adalah kasus mantan Kepala Badan Reserse Kriminal Kepolisian Negara Republik Indonesia, Komisaris Jenderal Susno Duadji yang melaporkan adanya kejahatanyang terjadi secara sistematis dan terstruktur di institusi Kepolisian Republik Indonesia kepada Satuan Tugas Pemberantasan Mafia Hukum pada tanggal 18 Maret 2010 dan 12 April 2010 dengan melaporkan: ${ }^{9}$

a. Tindak pidana dan pencucian uang yang diduga dilakukan oleh tersangka Gayus Tambunan;

b. Tindak pidana korupsi/suap pada kasus PT. Salmah Arwana Lestari;

c. Penggunaan anggaran di Mabes Polri dan Polda-Polda seluruh Indonesia.

Laporan Susno Duadji yang paling signifikan dalam mengungkap kejahatan korupsi adalah laporan mengenai tindak pidana pencucian uang oleh Gayus Tambunan. Susno mengungkapkan adanya makelar kasus dalam penyidikan kasus pajak senilai Rp. 25.000.000.000,- di Markas Besar Kepolisian Negara Republik Indonesia. Laporan tersebut lalu mengungkap keberadaan mafia pajak, yakni Gayus Tambunan yang mengakui bahwa dirinya telah membagikan uang sejumlah Rp. 5.000.000.000,- kepada jaksa, polisi, dan hakim. ${ }^{10}$

Namun demikian, kontribusi Susno Duadji dalam mengungkap kejahatan korupsi, mafia hukum, dan mafia pajak ini tidak diapresiasi oleh Negara. Susno Duadji justru diputus bersalah atas kasus yang dilaporkannya sendiri yakni: (1) suap PT. Salmah Arwana Lestari, dan (2) korupsi pengamanan dana Pemilihan Kepala Daerah Jawa Barat, yang merupakan kasus lain. Adapun amar putusan majelis hakim berbunyi sebagai berikut: ${ }^{11}$

9 Lihat Putusan Mahkamah Konstitusi Nomor 42/ PUU-VIII/2010.

10 Kompas, Kedudukan "Whistle Blower" Perlu Diperkuat, Op.cit.

11 Kompas, Susno Langsung Ajukan Banding, diakses dari http://nasional.kompas.com/ read/2011/03/24/20203494/Susno.Langsung.
1. Menyatakan terdakwa Susno Duadji telah terbukti secara sah dan meyakinkan bersalah melakukan tindak pidana korupsi;

2. Menjatuhkan pidana terdakwa 3 tahun 6 bulan dan denda Rp. 200.000.000,-serta subsider 6 bulan kurungan;

3. Menghukum Susno Duadji membayar uang pengganti Rp. 4.000.000.000,-

Di samping kasus Susno Duadji, kasus justice collaborator lainnya adalah kasus Agus Condro. Dimana Agus Condro melaporkan kepada Komisi Pemberantasan Korupsi (KPK) mengenai dugaan suap cek pelawat (travel cheque) bagi anggota DPR periode 2004-2009, saat pemilihan Miranda Goeltom menjadi Deputi Gubernur Senior Bank Indonesia pada tahun 2004. Agus Condro juga mengakui bahwa dirinya menerima cek pelawat senilai Rp. 500.000.000,pada Agustus 2008. Atas laporan yang disampaikan oleh Agus Condro tersebut, KPK sudah menetapkan 24 anggota DPR sebagai tersangka pada 4 Februari 2011. Ironisnya, Agus Condro juga termasuk ke dalam 24 tersangka tersebut. ${ }^{12}$

Kasus Susno Duadji dan Agus Condro menunjukkan bahwa negara tidak memberikan perlindungan bagi justice collaborator. Hal ini merupakan langkah mundur bagi upaya pemberantasan korupsi sebab justice collaborator memiliki peran strategis dalam mengungkap kejahatan korupsi.

Dalam sistem hukum Indonesia, perlindungan hukum justice collaborator diatur dalam tiga jenis peraturan yakni: Undang-Undang Nomor 13 Tahun 2006; Surat Edaran Mahkamah Agung; dan Peraturan Bersama. Ketiga peraturan ini memiliki berbagai permasalahan materil dan formil yang merupakan penyebab lemahnya perlindungan hukum justice collaborator.

Undang-Undang Nomor 13 Tahun 2006 tidak memberi perlindungan maksimal bagi justice collaborator. Ketentuan UndangAjukan.Banding

12 Kompas, KPK Tahan 24 Tersangka Cek Pelawat, diakses dari http://nasional.kompas. com/read/2011/02/04/20040177/KPK.Tahan.24. Tersangka.Cek.Pelawat 
Undang Nomor 13 Tahun 2006 bahkan menjadi dasar untuk memidanakan justice collaborator atas kasus yang dilaporkannya, sebagaimana diatur berikut ini: ${ }^{13}$

"Seorang Saksi yang juga tersangka dalam kasus yang sama tidak dapat dibebaskan dari tuntutan pidana apabila ia ternyata terbukti secara sah dan meyakinkan bersalah, tetapi kesaksiannya dapat dijadikan pertimbangan hakim dalam meringankan pidana yang akan dijatuhkan."

Ketentuan di atas mengindikasikan bahwa, kontribusi justice collaborator hanya dijadikan pertimbangan hakim dalam meringankan pidananya. Namun, ketentuan tersebut tidak memiliki daya mengikat yang mewajibkan hakim untuk memberi keringanan pidana, sehingga tidak ada jaminan bagi justice collaborator untuk mendapat keringanan pidana.

Pembentukan Undang-Undang Nomor 13 Tahun 2006 sejak awalnya memang tidak ditujukan untuk mengatur justice collaborator. Hal ini dinyatakan oleh Harkristuti Harkrisnowo sebagai wakil Pemerintah dalam Sidang Perkara Pengujian Undang-Undang Nomor 13 Tahun 2006, bahwa: ${ }^{14}$

...Latar belakang Undang-Undang Perlindungan Saksi, yang kebetulan saya sendiri yang merancang waktu itu, yang sebenarnya memang tidak ada keinginan dari perancang undang-undang untuk memasukkan whistle blower ke dalam ketentuan, karena kita tahu bahwa Saksi dan whistle bloweratau saya sebut sebagai pemukul kentongan bahasa Indonesianya, itu adalah 2 kelompok yang berbeda walaupun mereka sama-sama orang yang memberikan keterangan dalam proses peradilan... Berkaitan dengan equivalency antara Saksi dengan whistle

13 Pasal 10 ayat (2) Undang-Undang Nomor 13 Tahun 2006 tentang Perlindungan Saksi dan Korban

14 Risalah Sidang Perkara Nomor 42/PUUVIII/2010, 19 Agustus 2010, Perihal Permohonan PengujianUndang-Undang Nomor 13 Tahun 2006 Tentang Perlindungan Saksi dan Korban Terhadap Undang-UndangDasar Negara Republik Indonesia Tahun 1945. blower. Di negara-negara yang disebut oleh para Ahli ini memang ditemukan Whistle Blower Act, tapi di negara tersebut juga ada Victim and Witness Protection Act mereka berada dalam 2 rezim hukum yang berbeda.

Putusan Mahkamah Konstitusi semakin menguatkan pernyataan bahwa UndangUndang Nomor 13 Tahun 2006 tentang Perlindungan Saksi dan Korban memang tidak ditujukan untuk mengatur justice collaborator, bahwa: ${ }^{15}$

Mahkamah berpendapat bahwa UndangUndang a quo memang tidak mengatur tentang whistle blower. Terkait dengan hal tersebut Mahkamah sependapat dengan keterangan Pemerintah yang menyatakan, "Kerumitan posisi whistle blower (pemukul kentongan) tersebut menyebabkan para perumus undangundang a quo memutuskan untuk tidak memasukkan tentang whistle blower".

Dengan demikian, Undang-Undang Nomor 13 Tahun 2006 belum memberikan perlindungan hukum maksimal justice collaborator. Hal ini juga diakui oleh Mas Achmad Santosa, bahwa saksi pelaku sekaligus pengungkap adanya korupsi tidak mendapatkan perlindungan dalam sistem hukum Indonesia. ${ }^{16}$

Sebagai upaya untuk mengatasi kekosongan hukum dalam melindungi justice collaborator, Mahkamah Agung menerbitkan Surat Edaran Nomor 4 Tahun 2011 tentang Perlakuan bagi Pelapor Tindak Pidana (Whistleblower) dan Saksi Pelaku yang Bekerjasama (Justice Collaborator) di dalam Perkara Tindak Pidana Tertentu.

Surat Edaran Mahkamah Agung (SEMA) berisi himbauan kepada Para Hakim agar dapat memberikan perlakuan khusus dengan memberikan keringanan pidana dan/atau bentuk perlindungan lainnya terhadap orangorang yang dikategorikan sebagai pelapor

15 Lihat Putusan Mahkamah Konstitusi Nomor 42/ PUU-VIII/2010.

16 Sentra Informasi dan Data untuk Anti Korupsi, "Whistle Blower" Belum Terlindung, diakses darihttp:// infokorupsi.com/id/korupsi.php?ac=8235\&l=-belumterlindung 
tindak pidana (whistleblower) dan saksi pelaku yang bekerjasama (justice collaborator).

Menurut SEMA, pedoman untuk menentukan seseorang sebagai justice collaborator adalah sebagai berikut:

a. Yang bersangkutan merupakan salah satu pelaku tindak pidana tertentu sebagaimana dimaksud dalam SEMA ini, mengakui kejahatan yang dilakukannya, bukan pelaku utama dalam kejahatan tersebut serta memberikan keterangan sebagai saksi di dalam proses peradilan;

b. Jaksa Penuntut Umum di dalam tuntutannya menyatakan bahwa yang bersangkutan telah memberikan keterangan dan bukti-bukti yang sangat signifikan sehingga penyidik dan/atau penuntut umum dapat mengungkap tindak pidana dimaksud secara efektif, mengungkap pelakupelaku lainnya yang memiliki peran lebih besar dan/atau mengembalikan aset-aset/hasil suatu tindak pidana;

c. Atas bantuannya tersebut, maka terhadap Saksi Pelaku yang Bekerjasama sebagaimana dimaksud di atas, hakim dalam menentukan pidana yang akan dijatuhkan dapat mempertimbangkan hal-hal penjatuhan pidana sebagai berikut:

i. Menjatuhkan pidana percobaan bersyarat khusus; dan/atau;

ii. Menjatuhkan pidana berupa pidana penjara yang paling ringan di antara terdakwa lainnya yang terbukti bersalah dalam perkara dimaksud.

Dalam pemberian perlakuan khusus dalam bentuk keringanan pidana hakim tetap wajib mempertimbangkan rasa keadilan masyarakat.

SEMAtelah mengatur lebih lanjutmengenai kriteria serta mekanisme penanganan perkara yang melibatkan justice collaborator. Namun, pada dasarnya ketentuan dalam SEMA masih memiliki banyak kelemahan dari segi materil yakni: a. Tidak diaturnya hak dan bentuk perlindungan bagi justice collaborator;

b. Ketentuan keringanan pidana bagi justice collaborator hanya dijadikan pertimbangan hakim dan tidak memiliki daya mengikat yang mewajibkan hakim untuk memberi keringanan pidana.

Di samping itu, SEMA juga memiliki kelemahan dari segi formil yakni lingkup keberlakuan SEMA hanya mengikat kalangan Mahkamah Agung, yakni hakim. Padahal perlindungan justice collaborator idealnya harus melibatkan seluruh instansi penegak hukum. Dengan demikian, SEMA belum memberi perlindungan hukum maksimal bagi justice collaborator.

Peraturan Bersama Menteri Hukum dan HAM, Jaksa Agung, Kepala Kepolisian, Komisi Pemberantasan Korupsi, Ketua Lembaga Perlindungan Saksi dan Korban tentang Perlindungan bagi Pelapor, Saksi Pelapor dan Saksi Pelaku yang Bekerjasama (selanjutnya disebut Peraturan Bersama), cukup komprehensif dalam mengatur bentuk perlindungan bagi justice collaborator.

\section{Hambatan-Hambatan Perlindungan Hukum Bagi Keberadaan Whistleblower Dan Justice Collaborators Pada Pengungkapan Korupsi Yang Berbasis Nilai Keadilan}

Hambatan-hambatan perlindungan hukum bagi keberadaan Whistleblower dan Justice Collaborator pada pengungkapan korupsi yang berbasis nilai keadilan, diketahui dari sisi substansi hokum adalah kelemahan pengaturan tentang Justice collaborator secara eksplisit hanya diatur dalam Surat Edaran Mahkamah Agung Nomor 4 Tahun 2011 tentang perlakuan bagi pelapor tindak pidana (Whistleblower) dan saksi pelaku yang bekerjasama (Justice Collaborator) di dalam perkara pidana tertentu, sehingga SEMA tersebut tidak mempunyai kekuatan hukum yang mengikat seperti halnya Undang-Undang. Hal ini karena kurangnya pemahaman dari penegak hukum khususnya di daerah karena kurangnya sosialisasi, 
dari kendala sisi struktur hukum adalah berkaitan dengan kelembagaan LPSK, diantaranya kedudukan LPSK yang mandiri namun harus menjalankan program yang harus di dukung oleh instansi penegak hukum khususnya dalam hal perlindungan Justice Collaborator dalam bentuk pemberian penanganan khusus. kemudian terkait tugas dan kewenangan kerjasama dengan instansi terkait dalam praktik sulit diterapkan selanjutnya dari struktur dan infrastruktur LPSK. beberapa hal yang menjadi hambatan dan masalah bagi Lembaga Perlindungan Saksi dan Korban (LPSK) diantaranya adalah sebagai berikut

1. Belum adanya dasar hukum yang kuat untuk menjamin perlindungan terhadap whistle blower, undang-undang yang ada masih bersifat umum terhadap saksi, pelapor dan korban. Kalau pun ada hanya berbentuk Surat Edaran Mahkamah Agung RI ("SEMA") yaitu SEMA Nomor 4 Tahun 2011 tentang Perlakuan Bagi Pelapor Tindak Pidana (Whistle Blower) dan Saksi Pelaku yang Bekerjasama (Justice Collaborator) di dalam Perkara Tindak Pidana Tertentu, dan Peraturan Bersama Kementerian Hukum dan HAM RI, KPK RI, Kejaksaan RI, Polri, dan LPSK tentang Perlindungan Bagi Pelapor, Saksi Pelapor dan Saksi Pelaku yang Bekerjasama.

2. Belum adanya pemahaman dan perspektif bersama aparat penegak hukum dalam memberikan perlindungan terhadap Whistle bower, kesepakatan bersama hanya di tingkat atasan, dan belum tersosialisasi di tingkat bawah maupun daerah.

3. Belum maksimalnya pemberian perlindungan terhadap whistle blower. Hal ini karena Hakim masih mengabaikan rekomendasi aparat penegak hukum terhadap status seseorang sebagai whistle blower. Ini juga disebabkan SEMA sifatnya tidak punya kekuatan hukum mengikat.

4. Peran LPSK masih terbatas dalam kewenangan yang dituangkan Undang-
Undang Nomor 13 Tahun 2006 tentang Perlindungan Saksi dan Korban;

LPSK yang merupakan lembaga yang notabenenya baru di Indonesia, masih memiliki banyak kelemahan dalam hal sarana dan fasilitas. Keterbatasan jumlah sumber daya manusia di LPSK menjadi kendala utama dalam memberikan perlindungan. Sebagaimana yang dituturkan oleh Tasman Gultom, bahwa idealnya berjumlah minimal seribu orang. ${ }^{17}$ Selain itu keberadaan LPSK yang baru ada di Jakarta menyulitkan pihak di daerah apabila ada whistleblower Faktor masyarakat dinilai merupakan faktor yang paling utama dalam pelaksanaan proses perlindungan terhadap whistleblower yakni lingkungan dimana hukum tersebut berlaku atau diterapkan;

Masyarakat yang dimaksud dalam penelitian ini adalah LPSK dan KPK. Hambatan yang dialami oleh LPSK dalam memberikan perlindungan hukum kepada whistleblower.

\section{PENUTUP}

\section{Kesimpulan}

1. Perlindungan hukum keberadaan saksi dan korban sebagai Whistleblower dan Justice Collaboratos pada pengungkapan korupsi belum berbasis nilai keadilan, dapat diketahui bahwa status hukum dari seorang whistle blower tidak berhenti hanya sebatas whistle blower saja, suatu saat kedudukan tersebut dapat berubah menjadi seseorang harus dimintai pertanggungjawaban. Sesuai teori kepentingan negara melawan kepentingan individu, bahwa demi menunjang kepentingan negara dalam mengungkapkan suatu kejahatan whistle blower sebagai individu dapat dilepaskan dari bentuk pertanggungjawaban. Dengan demikian atas kepentingan negara, tujuan hukum berupa kemanfaatan

17 Jumlah SDM LPSK adalah 170 orang (enam diantaranya adalah komisioner). Hasil Wawancara dengan Tasman Gultom. 
maka perlu dibuat perlindungan hukum bagi whistle blower. Walaupun dari segi tujuan hukum kepastian hukum, apa-apa yang telah dilakukan whistle blower dan perlu dimintai pertanggungjawaban maka haruslah ditindak secara tegas pertanggungjawaban.

2. Hambatan-hambatan perlindungan hukum bagi keberadaan Whistleblower dan Justice Collaboratos pada pengungkapan korupsi yang berbasis nilai keadilan, diketahui dari sisi substansi hokum adalah kelemahan pengaturan tentang Justice collaborator secara eksplisit hanya diatur dalam Surat Edaran Mahkamah Agung Nomor 4 Tahun 2011 tentang perlakuan bagi pelapor tindak pidana (Whistleblower) dan saksi pelaku yang bekerjasama (Justice Collaborator) di dalam perkara pidana tertentu, sehingga SEMA tersebut tidak mempunyai kekuatan hukum yang mengikat seperti halnya Undang-Undang. Hal ini karena kurangnya pemahaman dari penegak hukum khususnya di daerah karena kurangnya sosialisasi, dari kendala sisi struktur hukum adalah berkaitan dengan kelembagaan LPSK, diantaranya kedudukan LPSK yang mandiri namun harus menjalankan program yang harus di dukung oleh instansi penegak hukum khususnya dalam hal perlindungan Justice Collaborator dalam bentuk pemberian penanganan khusus. Kemudian terkait tugas dan kewenangan kerjasama dengan instansi terkait dalam praktik sulit diterapkan selanjutnya dari struktur dan infrastruktur LPSK.

\section{Saran}

1. Pemerintah dan DPR perlu mengamandemen Pasal 2 UndangUndang No. 31 Tahun 2006 dan pasal 5(1) a Undang-Undang No.31 Tahun 2014 Tentang Perubahan UndangUndang No.13 Tahun 2006 Tentang perlindungan saksi dan korban.

2. Kepada aparat penegak hukum yang menangani perkara tindak pidana korupsi, walaupun hingga saat ini belum ada peraturan perundangundangan yang mengatur secara tegas tentang Justice collaborator, namun kiranya dapat lebih memperhatikan keberadaan Justice collaborator serta dapat memberikan perlindungan yang optimal sehingga keberadaan Justice collaborator dalam peradilan pidana dapat memberikan peran yang maksimal dalam mengungkap tindak pidana dan pelaku utama lainnya dalam jaringan tindak pidana terorganisir

\section{DAFTAR PUSTAKA}

\section{- Buku-buku}

Jimly Assiddiqie, 2007, Pokok-Pokok Hukum Tata Negara Indonesia Pasca Reformasi, PT. Bhuana IImu Populer, Jakarta;

Friedrich, CJ, 2010, Filsafat Hukum Perspektif Historis, Nuansa dan Nusamedia, Bandung;

Ronny Hannitijo Soemitro, 1990, Metodologi Penelitian Hukum dan Jurumetri, Ghalia Indonesia, Jakarta;

Teguh Sulistia dan Aria Zurnetti, 2011, Hukum Pidana Horizon Pasca Reformasi, PT. Raja Grafindo Persada, Jakarta; 
- Karya Ilmiah dan Jurnal:

Jimly Assiddiqie, 2001, Telaah Kritis Mengenai Perubahan Undang-Undang Dasar 1945, Jurnal Forum Indonesia Satu "Civility", Vol. 1, No. 2, November 2001-Januari 2002, Jakarta

\section{- Website:}

http://www.dw.com/id/indeks-korupsi-peringkat-indonesia-membaik-tapi-masihburuk/a-18107694

http://cpi.transparency.org/cpi2012/results/

http://www.mahfudmd.com/index.php?page=web.MakalahVisit\&id=25 